Dvorský, J., Petráková, Z., Mezuláník, J., \& Caha, Z. (2021). Impact of social environment indicators on students' propensity to do business: Case study from central European countries. Journal of International Studies, 14(3), 205-219.

doi:10.14254/2071-8330.2021/14-3/13

\title{
Impact of social environment indicators on students' propensity to do business: Case study from central European countries
}

\author{
Ján Dvorský \\ Faculty of Management and Economics, \\ Tomas Bata University in Zlin, \\ Czech Republic \\ dvorsky@utb.cz \\ ORCID 0000-0002-6078-2636
}

\section{Zora Petráková}

Faculty of Civil Engineering,

Slovak University of Technology,

Slovak Republic

zora.petrak.ova@stuba.sk.

ORCID 0000-0002-1398-9415

\section{Jiří Mezuláník}

Institute of Entrepreneurship and Marketing,

University of Entrepreneurship and Law,

Czech Republic

jïr.mezulanik@,vspp.cz.

\section{Zdeněk Caha}

Faculty of Corporate Strategy,

Institute of Technology and Business in Ceské Budéjovice,

Czech Republic

caba@mail.vstecb.cr.

ORCID 0000-0003-2363-034X

Abstract. The aim of the article is to identify and quantify the impact of selected social environment indicators on students' propensity to do business. A survey-based questionnaire was conducted with students in the last year of their economic studies at 25 universities. The database contains 1,352 filled-out questionnaires showing Slovak, Czech and Polish students' attitudes. A linear regression analysis was used to evaluate the formulated hypotheses. This approach was implemented separately for each country (Czech Republic - CR, Slovakia - SR, and Poland PL). The results showed several findings. The comparison of social environment 
indicators' impact on students' propensity to do business confirmed common attitudes (significant indicator - support of family environment; not significant indicator - media) of students based on their nationality. The businessperson in a student's family is the most important social environment indicator according to students' attitudes for each country. The fact that society generally appreciates business people has a positive impact on Czech and Slovak students' propensity to do business. Politicians and public perception of entrepreneurs as a social indicator has a negative impact on Czech students' propensity to do business. The results are important for national and non-profit organizations that help young people to start a business.

Keywords: propensity to do business, case study, impact, student, social environment, linear regression

JEL Classification: H70, L26, M13, M21

\section{INTRODUCTION}

Young people start working as employees in enterprises or government institutions (Hussain et al., 2021; Draskovic et al., 2020). Self-employment for them is not interesting, because their skills and financial situation is not easy. Minimum students of economic universities start the business immediately after finished studies (Ojewumi \& Fagbenro, 2019).

One of the goals of economic universities is to prepare young people for professional life. Also, the national education sector of each country must help with their potential business activities (Clarke et al., 2017). This topic about the importance of entrepreneurship is interesting for academic people, which present their scientific articles in conferences and scientific articles (e.g. Zygmund, 2018; Dacin et al., 2010).

Entrepreneurs are significant for each state because they create innovations, new work positions and improve competitiveness in many business sectors (Lewandowska \& Stopa, 2018; Luchko et al., 2019).

Many authors think that the entrepreneur's education (university education; business courses, knowledge, and workshops) has a positive effect on their entrepreneur's intentions (e.g. Sansone et al., 2021; Chaita \& Sibanda, 2021; Zaring et al., 2021; Bae et al., 2014). Interaction between academic institutions and the business environment in SMEs is important for activating students to start new businesses (Goraczkowska, 2020; Cera et al., 2020; Jones et al., 2017). In this context, the role of the entrepreneur is one of the key factors for success in business (van Stel et al., 2020). The quality of the university education in economic faculties of V4 countries (number of economic faculties: CR - 21; SR - 24; PL - 60) is at a lower level than in western EU countries (Vašenda, 2019). Education in the field of the role of the entrepreneur in SMEs is not a priority at the faculties of economics in the V4 countries (Kuncová \& Mulač, 2017).

This paper analyzes the influences of social environment indicators (the businessperson in a student's family; the society's approach to entrepreneurs; perception of politician's and the public's approach to the usefulness of entrepreneurs to society; the approach of media to the true information about activities of businessperson) of the students' propensity to do business. The originality of the case study is in the identification and quantification of the social environment indicators shaping the entrepreneurial propensity of university students to do business. Also, the comparison of the selected social indicators between three central European countries brings important findings.

The article's structure. The theoretical review shows the empirical results on the students' propensity to do business. The next section of the article formulates the aim of the case study, the materials and 
methods, the data collection, the hypotheses, the statistical methods, and the basic structure of students. The next section contains the empirical results and discussion. The conclusion demonstrates the important results of case study, imitations, and future focus of the research.

\section{LITERATURE BECKGROUND}

Many authors think that the people with economic higher education (minimum master's degree) are a driving force of any economy because they have natural intellect, practical skills (acquired during the study), and academic knowledge (e.g. Zao et al., 2021; Dvorsky et al., 2019). Entrepreneurs with their optimistic temperament and activity, are helping their countries to develop. Factors that determining young people's entry into entrepreneurship include: social indicator (Marques et al., 2018), microeconomic environment (Khan et al., 2019), access to funds (Zajtkowski \& Domanska, 2019; Sobekova Majkova \& Kljucnikov, 2017), quality of higher education (Nabi et al., 2018; Suroso et al.; 2020), personality traits (Etzal \& Nagy), quality of the business environment (Belas et al., 2020), and so on.

The role of education in the process of shaping the entrepreneurial tendency of university students is perceived by authors from different perspectives (Popescu et al., 2016; Jones et al., 2011). They report that entrepreneurship education and knowledge at universities can positively determine students' decision to become entrepreneurs. If universities create a positive environment and support entrepreneurial activities as part of their educational activities, students are more motivated to start a business.

In this context, according to OECD (2018), the education expenditure per student in the selected countries in 2015 was the following: 9687 USD in Poland, 10891 USD in the Czech Republic, and 15874 USD in Slovakia. It covers expenditure on schools, universities and other public/private educational organizations. The expenditure contains supporting services for students and their families provided by educational organizations.

Gurol \& Atsan (2006) said, that the social indicators and social environment of a country have a positive influence on the student propensity to start a new business. In this context, the significant social environment indicator (SEs) as family (Heck et al., 2006), politicians (Goktan \& Gupta, 2015), media, and society (Baryniene et al., 2014).

Marques et al. (2018) state in their research results that education in business theory has the most significant impact on business and social sciences students. Family environment and demographic characteristics of students (such as gender) are variables with a positive impact on individual entrepreneurial orientation. Basic indicators of emotional support in entrepreneurship are family environment (children, wife/husband, children, and parents); friends, and community (Klyver et al., 2018). These factors, in their turn, can lead to creation of individual entrepreneurial values (Eyel et al., 2020). They have some specific differences connected with gender and other factors (Çera et al., 2018), however, in general social environment, particularly, family, can be a powerful driver for students' intention in employment and business sphere (Tvaronavičienè et al., 2021).

Family environment, self-concept, motivation, and risk-taking propensity have a significant and positive effect on university students' interest in entrepreneurship (Hahn et al., 2020). The family environment highly affects university students' interest in doing entrepreneurship. Self-concept allows recognizing the environment easier and faster and spot business opportunities better (Carrasco Sierra et al., 2020).

H1: Family has a positive impact on the students' propensity to do business in the entrepreneurial environment.

A key dilemma facing young entrepreneurs is how to finance their ventures (Gruenhagen, 2020; Belas et al., 2019). While entrepreneurs in developed economies can seek VC or angel investment, entrepreneurs in emerging economies often need to pursue potential government funding opportunities (Armanios et al., 
2017). Vega-Gómez et al. (2020) showed that the business size and the public support in the field of training and bureaucracy are the main elements that affect success. Rodríguez-Gulías et al. (2020) found the good effect of government on entrepreneurial intention and business creation.

In this context, Kallas \& Parts (2020) found that regarding differences between entrepreneurs and nonentrepreneurs, entrepreneurs have a more positive perception of the business environment and the ease of doing business, including the simplicity of entrepreneurship-related legislation. On the other hand, entrepreneurs are more skeptical about the availability of financial resources, and they perceive public attitudes and the role of entrepreneurs in a society less positively.

Many studies showed that developing positive attitudes towards entrepreneurship is relevant factor in all stages of becoming an entrepreneur (e.g. Anor Salim et al., 2019; Yousaf et al., 2021; Kallas \& Parts, 2020). Financing opportunities both from private and public institutions and keeping entrepreneurship legislation simple and transparent have the utmost importance in increasing the share of entrepreneurs and entrepreneurship-related benefits in society (Kallas \& Parts, 2020). In this regard the personal perception of social justice in economic environment, particularly, distributive justice, can significantly influence the propensity to participate in any initiatives (Mishchuk et al., 2019). The perception of the business environment and its support by politicians is essential in the decision-making regarding starting entrepreneurial activities (Rogalska, 2018; Robertson et al., 2000). In this context, Belás et al. (2015) said that the important roles are played by the social environment and the political and legal environments that are created by the state authorities. Presumably, a positive perception of these companies by their environment could stimulate their financial performance and accelerate the positive influences of these companies on society.

Society (H2) and politicians (H3) have a positive impact on the students' propensity to do business in the entrepreneurial environment.

True media information about the status of SMEs in the business environment has a strong impact on the reputation of the company (Ramos-González et al., 2021) and its financial performance (Castaño et al., 2015). Social media play a key role (e.g. Facebook, Instagram, what-up, and so on) in the good reputation of SMEs (Franco \& Haase, 2020).

Partanen \& Goel (2017) found that reputation is an important source for demonstrating technological capabilities and firm sustainability to potential customers, especially for young firms. Moon et al. (2021) said in this context, that especially social media have a significant role in the reputation of firms.

H4: Media has a positive impact on the students' propensity to do business in the entrepreneurial environment.

\section{AIM, METHODOLOGY AND DATA}

The aim of the article is to identify and quantify the impact of selected social environment indicators on students' propensity to do business. One part of the article was a comparison of the Czech (CR), Slovak (SR), and Polish (PL) students' relationship between social environment indicators and the propensity to do business.

The respondent (hereinafter "student") is characterized as a student in the last year of their economic studies at a university. The data collection was realized in the years 2017 and 2018. The mathematical function (Randbetween) was applied to the random choice of economic universities (and their students) separately for each country of the case study (Dvorsky et al., 2018). The online questionnaires were addressed to students in their national languages. The exact formulation of questions in the questionnaire for Slovak and Czech students as follows:

https://docs.google.com/forms/d/e/1FAIpQLSdEtePpSyjA1cYlVmDJ2vYZ0LfOy8TbTMfQTWjEn2I Yi83YoQ/viewform 
The data set of students' attitudes ( $\mathrm{n}=1,352 ; 568$ answers from Slovak universities, 409 answer from Czech universities and 375 answers from Polish universities) was constructed to the end of the 2018 calendar year. The results of the sample size analysis confirmed that the range of each research sample is more than 271 respondents (the margin error - 5\%; the confidence level - 90\%; the number of students approx.: SR 0.235 mil.; CR - 0.5 mil.; PL - 2.145 mil.; the response distribution - 50\%). The research samples of students are adequate for each country. For the better evaluation of the representativeness of research samples were contacted students according to the geographical location (cities) of universities in selected countries (for more details see the demographic structure of students).

The questionnaire consisted of 43 questions divided into several parts. The first part of the questionnaire listed the basic characteristics of the student (gender, country, name of the university they attend). The second part of the questionnaire contained statements concerning the social environment, business support from the state, macroeconomic environment, quality of the business environment, access to financial resources, quality of university education, personal traits. The third part of the questionnaire contained allegations concerning business advantages and business disadvantages. The fourth part of the questionnaire examined the students' attitudes on their propensity to do business. The indicators were formulated into statements to which the students could react in one of the following ways: I agree completely (numerical value $(\mathrm{NV})=5$ ), I agree $(\mathrm{NV}=4)$, No attitude $(\mathrm{NV}=3)$, I disagree $(\mathrm{NV}=2)$, I disagree completely $(\mathrm{NV}=1)$. The hypotheses $(\mathrm{H} 1, \ldots, \mathrm{H} 4)$ were formulated as support on assessment of disparities between respondents according to the student's nationality (H1_SR, ...., H4_PL).

To meet the aim of the article, the following SEs were formulated:

\section{Social environment indicators (SEs):}

SE1: There is a businessperson in my family, and I highly respect him/her.

SE2: Society in general appreciates business people.

SE3: Politicians, as well as the public, consider business people beneficial for the society.

SE4: Media provide true information regarding the status and activities of business people.

\section{Propensity to do business (PB):}

PB: I am very interested in business.

Applying regression analysis in many empirical studies is a means of predicting a dependent variable in the future (for example: Marikina, 2018; Nava et al., 2018). The statistical method such as linear regression modeling can also be used to identify and quantify independent variables (social environment indicators) and to determine the direction and strength of the impact on students' propensity to do business. The fact is that all examined variables are identical metrics (same scaling of responses). A correlation matrix with pairwise correlation coefficients was used to determine the relationship between the dependent variable and the independent variables (James, 1964; Lancaster \& Hamdan, 1964). The significance of coefficients $\left(\beta_{s}\right)$ of independent variables were verified according to the Students' t-test. The Independent variable is statistically significant if the p-value of the t-test is less than the level of significance (Hair et al., 2010). The general form of the linear regression model (LRM) is as follows:

$$
P B_{i}=\beta 0+\beta 1 \times S E 1+\beta 2 \times S E 2+\beta 3 \times S E 3+\beta 4 \times S E 4+\varepsilon,
$$

where: $P B$ - dependent variable (propensity to do business); $i=1,2,3 ; 1-S R, 2-C R, 3-P L ; S E 1, \ldots$, SE4 - independent variables (indicators of social environment); $\varepsilon$ - random error.

The LRM is verified by regression characteristics such as the multiple correlation coefficient, determination coefficient, adjusted determination coefficient, and F-test (Breslow, 1990). The LRM is statistically significant if the p-value of the F-test (ANOVA - Analysis of variance) is lower than the level 
of significance (de Waal, 1977). The assumption of multicollinearity is verified in the regression model by using the variation factor of inflation (VIF - test) (Li \& Valliant, 2011). If the value of the VIF test for the independent variable is lower than 5, then this coefficient is not affected by multicollinearity (Arnold, 1990). The Shapiro-Wilk test (S-W test) was applied to verify the normal distribution of errors (de Waal, 1977). This assumption of the regression model is accepted when the p-value of the S-W test is higher than the level of significance. The Bartlett test was used to verify the assumption of homoscedasticity. This assumption is accepted if the p-value of the Bartlett test criterion is higher than the level of significance (Hair et al., 2010).

Basic evaluation of questions based on the characteristics of a student (nationality, gender, and city of study):

- nationality: $568(42.0 \%)$ students from SR; 409 (30.3\%) students from CR and $375(27.7 \%)$ students from PL;

- gender (together): 517 (39.2\%) males, 835 (61.8\%) females; 216 (38.03\%) males and $352(61.97 \%)$ females from SR; $156(38.14 \%)$ males and 253 (61.86\%) females from CR; 145 (38.7\%) males and 230 (61.3\%) females from PL

- city of study: PL - Toruń, Gdańsk, Szczecin; SR - Bratislava, Trenčín, Žilina, Banská Bystrica and Košice; CR - Prague, Liberec, Brno, Ostrava and Zlín.

Global Entrepreneurship Monitor (Bosma et al., 2020) showed that men are more active than females in the Total early-stage Entrepreneurial Activity in central European countries. On other hand, specifically for central European countries is typical that more females study in business universities than men (e.g. Vašenda, 2019). The respondent in the case study is a student.

\section{EMPIRICAL RESULTS}

The basic descriptive statistics (DS) of the social environment indicators based on the students' nationality are shown in Table 1.

Table 1

Descriptive analysis of selected indicators of the social environment

\begin{tabular}{|c|c|c|c|c|c|}
\hline \multirow{2}{*}{ DS } & \multicolumn{5}{|c|}{ Slovakia } \\
\hline & PB & SE1 & SE2 & SE3 & SE4 \\
\hline Mean & 3.504 & 3.838 & 3.211 & 2.588 & 2.537 \\
\hline Standard deviation & 1.061 & 1.151 & 0.967 & 0.937 & 0.852 \\
\hline Skewness & $-0.470^{*}$ & $-0.225^{*}$ & $-0.975^{*}$ & $-0.634^{*}$ & $-0.137^{*}$ \\
\hline Kurtosis & $-0.516^{*}$ & $-0.816^{*}$ & $-0.199^{*}$ & $0.312^{*}$ & $0.495^{*}$ \\
\hline \multirow{2}{*}{ DS } & \multicolumn{5}{|c|}{ Czech Republic } \\
\hline & PB & SE1 & SE2 & SE3 & SE4 \\
\hline Mean & 3.293 & 3.890 & 3.117 & 2.597 & 2.318 \\
\hline Standard deviation & 1.158 & 1.225 & 0.976 & 0.921 & 0.793 \\
\hline Skewness & $-1.014^{*}$ & $-0.185^{*}$ & $-1.119^{*}$ & $-0.449^{*}$ & $0.132^{*}$ \\
\hline Kurtosis & $-0.180^{*}$ & $-0.907^{*}$ & $-0.110^{*}$ & $0.394^{*}$ & $0.405^{*}$ \\
\hline \multirow{2}{*}{ DS } & \multicolumn{5}{|c|}{ Poland } \\
\hline & PB & SE1 & SE2 & SE3 & SE4 \\
\hline Mean & 3.688 & 3.507 & 3.085 & 3.299 & 2.371 \\
\hline Standard deviation & 1.198 & 1.932 & 1.089 & 1.022 & 0.961 \\
\hline Skewness & $-0.378^{*}$ & $-1.727^{*}$ & $-1.194^{*}$ & $-0.536^{*}$ & $-0.052^{*}$ \\
\hline Kurtosis & $-0.788^{*}$ & $-0.526^{*}$ & $-0.095^{*}$ & $-0.292^{*}$ & $0.490^{*}$ \\
\hline
\end{tabular}

Source: Authors' results. DS - Descriptive statistics; PB - Propensity to do business; SE1, ..., SE4 - independent variables; ${ }^{*}$ Normal distribution - confirmed. 
Correlation matrixes (see table 2; CM_SR, CM_CR, CM_PL) presents empirical results of the pairwise correlations (r) between the social environment indicators (each other, SE1, ..., SE4) and separately between the social environment indicators and the students' propensity to do business (PB).

Table 2

Dependences between variables

\begin{tabular}{|c|c|c|c|c|c|}
\hline \multirow{2}{*}{ CM_SR } & \multicolumn{5}{|c|}{ Slovakia } \\
\hline & PB & SE1 & SE2 & SE3 & SE4 \\
\hline $\mathrm{PB}$ & 1 & & & & \\
\hline SE1 & $0.256^{* *}$ & 1 & & & \\
\hline SE2 & $0.151^{*}$ & $0.115^{*}$ & 1 & & \\
\hline SE3 & -0.009 & $-0.077^{*}$ & $0.244^{* *}$ & 1 & \\
\hline SE4 & $0.026^{*}$ & 0.010 & $0.132^{*}$ & $0.223^{* *}$ & 1 \\
\hline \multirow{2}{*}{ CM_CR } & \multicolumn{5}{|c|}{ Czech Republic } \\
\hline & PB & SE1 & SE2 & SE3 & SE4 \\
\hline $\mathrm{PB}$ & 1 & & & & \\
\hline SE1 & $0.263^{* *}$ & 1 & & & \\
\hline SE2 & $0.191^{* *}$ & $0.208^{* *}$ & 1 & & \\
\hline SE3 & $-0.119^{*}$ & $-0.135^{* *}$ & $0.184^{* *}$ & 1 & \\
\hline SE4 & $0.042^{*}$ & 0.001 & $0.227^{* *}$ & $0.270^{* *}$ & 1 \\
\hline \multirow{2}{*}{ CM_PL } & \multicolumn{5}{|c|}{ Poland } \\
\hline & PB & SE1 & SE2 & SE3 & SE4 \\
\hline $\mathrm{PB}$ & 1 & & & & \\
\hline SE1 & $0.129^{*}$ & 1 & & & \\
\hline SE2 & $0.055^{*}$ & $-0.033^{*}$ & 1 & & \\
\hline SE3 & $0.039^{*}$ & $-0.042^{*}$ & $0.088^{*}$ & 1 & \\
\hline SE4 & $-0.022^{*}$ & -0.003 & $0.072^{*}$ & $0.042^{*}$ & 1 \\
\hline
\end{tabular}

Source: Authors' results. ${ }^{*} \alpha=0.05 ;^{* *} \alpha=0.01$; SE1, ..., SE4 - independent variables.

The results from the correlation matrix confirmed weak correlations between the social environment indicators (CM_SR: $\mathrm{r} \epsilon<-0.077$; 0.256>; CM_CR: $\mathrm{r} \epsilon<-0.135$; 0.263> and CM_PL: $\mathrm{r} \epsilon<-0.042$; 0.129>). All pairwise coefficients of correlation are statistically significant on $\alpha=0.05$, without the dependence between SE1 (Family) and SE4 (Media) for each groups of students based on their nationality.

The following Tables 3, 4, and 5 present empirical results of verifying the statistical significance of the LRMs (Table 3 - LRM1 in SR; Table 4 - LRM2 in CR; Table 5 - LRM3 in PL). 
The impact of social environment indicators on Slovak students' propensity to do business

\begin{tabular}{|c|c|c|c|c|c|}
\hline \multicolumn{6}{|c|}{ Linear Regression model - Slovakia (LRM1) } \\
\hline $\begin{array}{c}\text { Multiple correlation } \\
\text { Coefficient }\end{array}$ & \multicolumn{2}{|c|}{0.285} & $\begin{array}{c}\text { Adjusted coefficient of } \\
\text { determination }\end{array}$ & \multicolumn{2}{|c|}{0.075} \\
\hline Coefficient of determination & \multicolumn{2}{|c|}{0.081} & Standard error & \multicolumn{2}{|c|}{1.020} \\
\hline \multicolumn{6}{|c|}{ ANOVA - LRM1 } \\
\hline Characteristics & DF & SS & MS & \multicolumn{2}{|c|}{ F-test } \\
\hline Regression & 4 & 51.735 & 12.934 & \multicolumn{2}{|c|}{12.421} \\
\hline Residual & 563 & 586.258 & 1.041 & \multicolumn{2}{|c|}{ Sig. (P-value) } \\
\hline Total & 567 & 637.993 & & \multicolumn{2}{|c|}{$1.09 \mathrm{E}-09$} \\
\hline \multicolumn{6}{|c|}{ Regression function (LRM1) } \\
\hline $\begin{array}{l}\text { Independent } \\
\text { variables }\end{array}$ & $\beta$ & Standard Error & t-test & $\begin{array}{c}\text { Sig. } \\
\text { (p-val.) }\end{array}$ & VIF \\
\hline Intercept & 2.240 & 0.239 & 9.384 & 0.000 & - \\
\hline SE1 & 0.221 & 0.038 & 5.854 & 0.000 & 1.026 \\
\hline SE2 & 0.140 & 0.046 & 3.019 & 0.003 & 1.091 \\
\hline SE3 & -0.028 & 0.048 & -0.578 & 0.564 & 1.120 \\
\hline SE4 & 0.016 & & 0.303 & 0.762 & 1.059 \\
\hline
\end{tabular}

Source: Authors' results. DF - Degree of freedom; SS - Sum of Squares; MS - Mean Square; VIF - Variance inflation factor.

The empirical results from regression analysis (SR; see Table 3) show that the LRM of the relationships between the Slovak student's propensity to do business and the indicators of social environment is statistically significant (LRM1: F-test: p-value $=1.09 \mathrm{E}-09)$. The social environment indicators (SE1 and SE2) do have a statistically significant impact on the dependent variable (SE1: $\mathrm{p}$-value $=0.000$; SE2: $\mathrm{p}$-value $=0.003)$. The shape of LRM in SR is:

$$
\boldsymbol{P B}_{1}=2.240+0.221 \times \boldsymbol{S E} 1+0.140 \times \boldsymbol{S E} 2-0.028 \times \mathrm{SE} 3+0.016 \times S E 4+\varepsilon t,
$$

where: $P B$ - dependent variable (perception to do business); SE1,..., SE4 - independent variables (indicators of social environment); $\varepsilon t$ - random error.

The negative effect of the multicollinearity is not present in LRM1 (see table 3; VIF values are less than 5). Homoscedasticity and normal distribution of errors was accepted for LRM1 (Bartlett's test: p-value = 0.209; S-W test: $\mathrm{p}$-value $=0.342$ ). The assessment of scientific hypotheses: H1_SR and H2_SR were accepted; H3_SR and H4_SR were rejected (not significant SEs). 
The impact of social environment indicators on Czech students' propensity to do business

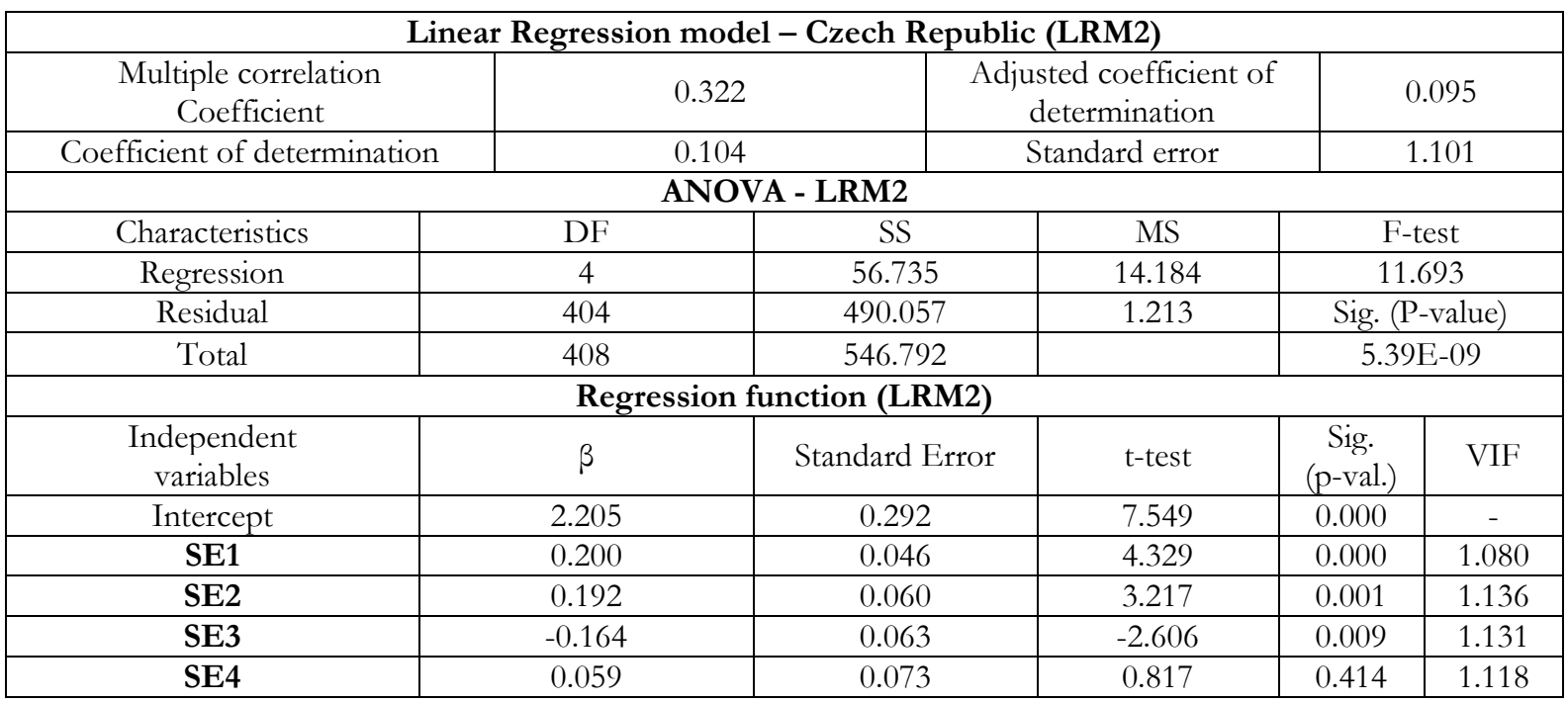

Source: Authors' results. DF - Degree of freedom; SS - Sum of Squares; MS - Mean Square; VIF - Variance inflation factor.

The empirical results from regression analysis (CR; see Table 4) show that the LRM of the relationships between the Czech student's propensity to do business and the indicators of social environment is statistically significant (LRM1: F-test: $\mathrm{p}$-value $=5.39 \mathrm{E}-09)$. The social environment indicators (SE1, SE2 and SE3) do have a statistically significant impact on the dependent variable (positive impact: SE1: $\mathrm{p}$-value $=0.000 ;$ SE2: $\mathrm{p}$-value $=0.001$; negative impact: SE3: $\mathrm{p}$-value $=0.009)$. The shape of LRM in CR is:

$$
\mathrm{PB}_{2}=2.205+0.200 \times \mathrm{SE} 1+0.192 \times \mathrm{SE} 2-0.164 \times \mathrm{SE3}+0.059 \times S E 4+\varepsilon_{t},
$$

where: $P B$ - dependent variable (perception to do business); SE1,.., SE4 - independent variables (indicators of social environment); $\varepsilon t$ - random error.

The negative effect of the multicollinearity is not present in LRM2 (see table 4; VIF values are less than 5). Homoscedasticity and normal distribution of errors was accepted for LRM2 (Bartlett's test: $\mathrm{p}$-value = 0.178; S-W test: $\mathrm{p}-$ value $=0.101)$. The assessment of scientific hypotheses: H1_CR, H2_CR were accepted; and H3_CR (negative impact) and H4_CR (not significant SE) were rejected. 
The impact of social environment indicators on Polish students' propensity to do business

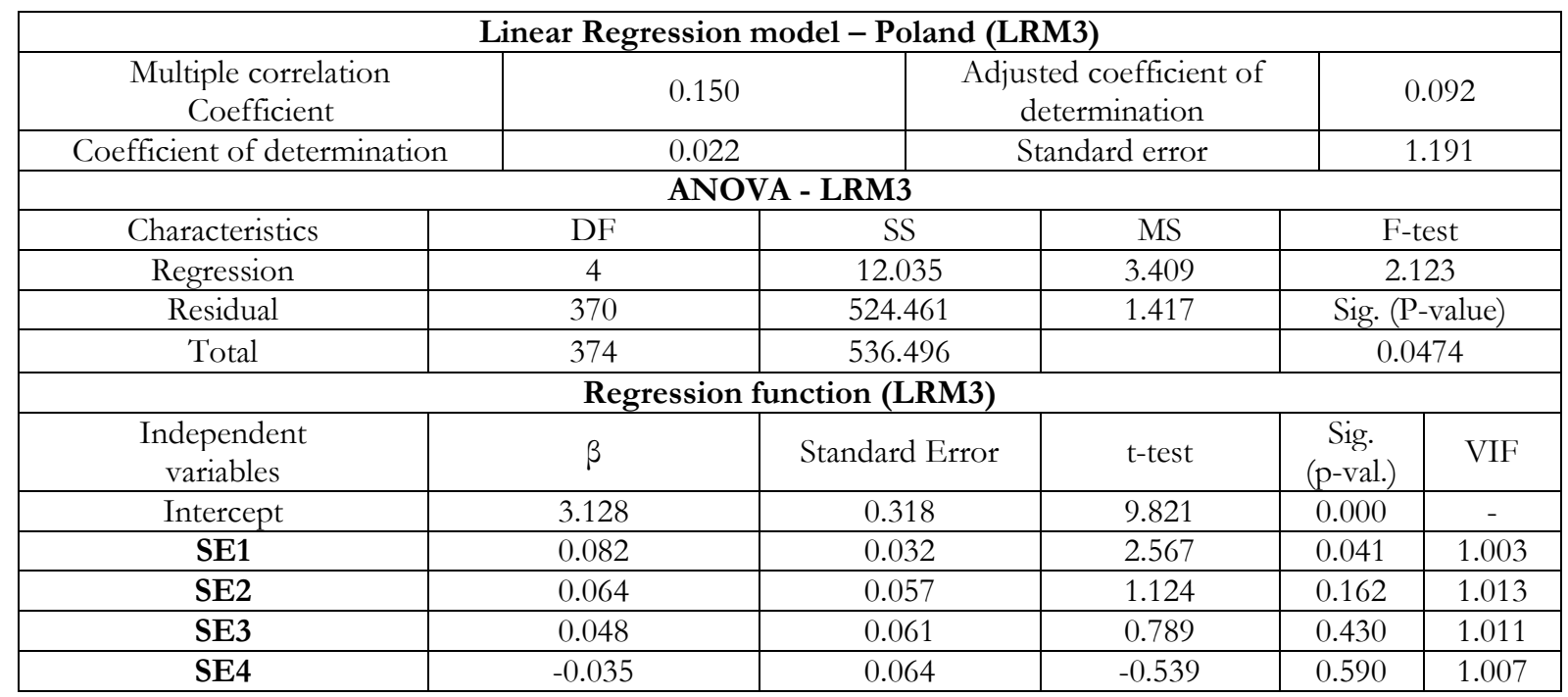

Source: Authors' results. DF - Degree of freedom; SS - Sum of Squares; MS - Mean Square; VIF - Variance inflation factor.

The empirical results from regression analysis (PL; see Table 5) show that the LRM of the relationships between the Polish student's propensity to do business and the indicators of social environment is statistically significant (LRM1: F-test: p-value = 0.0474). The social environment indicator (SE1) do has a statistically significant impact on the dependent variable $(\mathrm{SE} 1 \mathrm{:} \mathrm{p}$-value $=0.041)$. The shape of LRM in PL is:

$$
\boldsymbol{P B}_{3}=3.128+0.082 \times \boldsymbol{S E} 1+0.064 \times \mathrm{SE} 2+0.048 \times \mathrm{SE} 3-0.035 \times \mathrm{SE} 4+\varepsilon_{t},
$$

where: $P B$ - dependent variable (perception to do business); SE1,.., SE4 - independent variables (indicators of social environment); $\varepsilon t$ - random error.

The negative effect of the multicollinearity is not present in LRM3 (see table 6; VIF values are less than 5). Homoscedasticity and normal distribution of errors was accepted for LRM3 (Bartlett's test: $\mathrm{p}$-value = 0.137; S-W test: $\mathrm{p}$-value $=0.086$ ). The assessment of scientific hypotheses: H1_PL was accepted; H2_PL, H3_PL and H4_PL were rejected.

\section{DISCUSSION}

The Slovak students' propensity to do business is influenced by the family environment (SE1: $\mathrm{p}$-value $=0.000)$ and the fact that the society in general appreciates business people (SE2: $\mathrm{p}$-value $=0.003$ ). Otherwise, the impact of the media (SE4: $\mathrm{p}$-value $=0.564)$ and politicians $(\mathrm{SE} 3: \mathrm{p}$-value $=0.762)$ is not significant for Slovak students' propensity to do business. The most important indicator of the social environment, having the greatest positive impact on the Slovak students' propensity to do business, is the family environment $(\beta=0.221)$. The positive impact of the appreciation of business people by society $(\beta=$ $0.140)$ is also significant.

The Czech students' propensity to do business is influenced by the family environment (SE1: p-value $=0.000)$, the fact that society generally appreciates business people (SE2: $\mathrm{p}$-value $=0.001)$, and politicians $(\mathrm{SE3}$ : $\mathrm{p}$-value $=0.009)$. The impact of media was not confirmed $(\mathrm{SE} 4: \mathrm{p}$-value $=0.414)$. The most important indicator of the social environment, having the greatest positive impact on the Czech students' propensity 
to do business, is the family environment $(\beta=0.200)$. The positive impact of the appreciation of business people by society $(\beta=0.192)$ is also significant. The negative impact of the politicians on the Czech students' propensity to do business is also a significant indicator of the social environment $(\beta=-0.164)$.

The Polish students' propensity to do business is influenced by the family environment (SE1: $\mathrm{p}$-value $=0.041)$. Otherwise, the impact of the politicians $(\mathrm{SE3}$ : $\mathrm{p}$-value $=0.430)$, of the media (SE4: p-value $=$ $0.590)$, and the fact that society generally appreciates business people (SE2: $\mathrm{p}$-value $=0.162)$ is not significant for the Polish students' propensity to do business. The most important indicator of the social environment, having a positive impact on the Polish students' propensity to do business, is the family environment $(\beta=0.082)$.

The results of the case study are identical to the empirical results of Castano et al. (2015). Castano et al. (2015) said that social factors (such as family environment) have an important effect on students (study on economic Universities) in their future business activities (Lanero et al., 2016). Huggins et al. (2017) think that a significant factor is the motivation of students. In this context, the authors said, the state support and young entrepreneurs associations (or non-profit organizations) have a key role.

In this context, the universities can the various events and workshops design in order to share the best practices and help students acquire and develop necessary entrepreneurial skills during the semester in the academic year. The authors suggest the following events:

- Ask me anything. Local entrepreneurs, business community leaders, field professionals and other invited guests will share their experience, give tips and answer the questions of future entrepreneurs.

- $\mathrm{F}^{*} \mathrm{ckUp}$ nights. Events designed to show students that failure is nothing but a part of learning process. Here invited guests and course mentors will speak about their business failures, obstacles they had to face and overcome on their entrepreneurial journey.

- Digital workshop. Holding the digital workshop for the students in various area and familiarizing them with the digital learning platform and other supportive tools that were designed to improve the skills and make the business succeed (e.g. Google Digital Garage, Coursera etc.).

- Movie nights. Watching inspiring films being surrounded be the like-minded peers.

- Future is ours. A one-day marathon aimed at creating the sustainable solutions to the issues the world community is currently facing.

\section{CONCLUSION}

The aim of the article was to identify and quantify the impact of selected social environment indicators on students' propensity to do business.

The results showed that social environment indicators have an impact on the students' propensity to do business in each country of the case study. The family environment is the most important social environment indicator according to students' attitudes. The family environment positively determines the students' propensity to do business. Media is not a significant social environment indicator, as it does not determine the students' propensity to do business, according to the students.

The authors' efforts to obtain the largest possible sample of students in the last year of their economic studies $(n=1,352)$ from three central European countries can be considered limiting. On the other hand, the methodological part of the article describes students' information in detail. Another limit is the local nature of the research (only three countries from central Europe) and the statistical method such as linear regression modelling. Data collection was conducted before the pandemic COVID-19. It is also a limit of the case study. On other hand, the entrepreneurial intention to start a new business can be understood as opportunities to create a new company. 
The author's ambition is an effort to compare other factors (national support from the state, the business environment and her quality, financial management, university education, personal traits, business advantages and disadvantages) on students' propensity to do business according to the country of study. Therefore, there is an ongoing cooperation with economic universities in Hungary in order to obtain a relevant sample of students. At the same time, in the CR, SR and PL, the authors will again contact students in the last year of their economic studies with a request to complete a questionnaire for a re-verification of models and examination of the differences arising from the current COVID-19 pandemic.

\section{REFERENCES}

Anor Salim, F., Maidin, A., Mhd Sarif, S., \& Zainudin, D. (2019). The developing entrepreneurship training curriculum based on Tawhidic paradigm and legal principles: A case study of Malaysia. Economics, Management and Sustainability, 4(2), 30-39. doi:10.14254/jems.2019.4-2.3

Armanios, D. E., Eesley, C. E., Li, J., \& Eisenhardt, K. M. (2017). How entrepreneurs leverage institutional intermediaries in emerging economies to acquire public resources. Strategic Management Journal, 38(7), 1373-1390. doi:10.1002/smj.2575

Arnold, S. F. (1980). Asymptotic validity of F tests for the ordinary linear model and the multiple correlation model. Journal of the American Statistical Association, 75(372), 890-894. doi:10.1080/01621459.1980.10477568

Bae, T. J., Qian, S., Miao, C., \& Fiet, J. O. (2014). The relationship between entrepreneurship education and entrepreneurial intentions: A meta-analytic review. Entrepreneurship: Theory and Practice, 38(2), 217-254. doi:10.1111/etap.12095

Baryniene, J., Paužaite, Ž., \& Cibulskaite, J. (2014). Political and legal initiatives for systemic education of entrepreneurship. Public Policy and Administration, 13(3), 497-512. doi:10.5755/j01.ppaa.13.3.8385

Belas, J., Amoah, J., Petráková, Z., Kliuchnikava, Y. \& Bilan, Y. (2020). Selected Factors of SMEs Management in the Service Sector. Journal of Tourism and Services, 21(11), 129-146. doi:10.29036/jots.v11i21.215

Belas, J., Gavurova, B., Korony, S., \& Cepel, M. (2019). Attitude of university students toward entrepreneurship environment and toward entrepreneurship propensity in Czech republic and Slovak Republic-International comparison. Economic Research-Ekonomska Istrazivanja, 32(1), 2500-2514. doi:10.1080/1331677X.2019.1615972

Belás, J., Demjan, V., Habánik, J., Hudáková, M., \& Sipko, J. (2015). The business environment of small and mediumsized enterprises in selected regions of the Czech Republic and Slovakia. E a M: Ekonomie a Management, 18(1), 95-110. doi:10.15240/tul/001/2015-1-008

Bosma N., Hill, S., Ionescu-Somers, A., Kelley, D., Levie, J., \& Tarnawa, A. (2020). Global Entrepreneurship Monitor 2019/2020 Global report. London: Global Entrepreneurship Research Association.

Breslow, N. (1990). Tests of hypotheses in overdispersed poisson regression and other quasi-likelihood models. Journal of the American Statistical Association, 85(410), 565-571. doi:10.1080/01621459.1990.10476236

Carrasco Sierra, A., Cobos Flores, M.J., Fuentes Duarte , B., \& Hernández Comi, B.I. (2020). Successful Management System by a Metalworking Mexican Company During Covid-19 Situation. Analysis Through a New Index (Case Study). International Journal of Entrepreneurial Knowledge, 8(2), 42-55. doi: 10.37335/ijek.v8i2.116

Castaño, M., Méndez, M. \& Galindo, M. (2015). The effect of social, cultural, and economic factors on entrepreneurship. Journal of Business Research, 68(7), 1496-1500. doi:10.1016/j.jbusres.2015.01.040

Cera, G., Mlouk, A., Cera, E., \& Shumeli, A. (2020). The impact of entrepreneurship education on entrepreneurial intention. A quasi-experimental research design. Journal of Competitiveness, 12(1), 39-56. doi:10.7441/joc.2020.01.03

Clarke, I. E., Double, K. S., \& Maccann, C. (2017). Rethinking how we prepare students for the workforce: Commentary. Building better students: Preparation for the work.force (pp. 229-243) doi:10.1093/acprof:oso/9780199373222.003.00010

Dacin, P., Dacin, M., \& Matear, M. (2010). Social entrepreneurship: Why we don't need a new theory and how we move forward from here. Academy of Management Perspectives, 24(3), 37-57. doi: 10.5465/amp.24.3.37

Draskovic, V., Jovovic, R., Streimikiene, D., Bilan, S. (2020). Formal and Informal vs. Alternative Institutions. Montenegrin Journal of Economics, 16(2), 193-201 
Dvorský, J., Petráková, Z., Zapletalíková, E., \& Rózsa, Z. (2019). Entrepreneurial propensity index of university students. The case study from the Czech Republic, Slovakia and Poland. Oeconomia Copernicana, 10(1), 173-192. doi: 10.24136/oc.2019.009

Dvorsky, J., Rozsa, Z., Petrakova, Z., \& Kotaskova, A. (2018). Evaluation of state aid for entrepreneurs and their access to financial resources: Students' attitudes in Czech Republic, Poland and Slovakia. Marketing and management of innovations, 2018(3), 11-20. doi: 10.21272/mmi.2018.3-01

Etzel, J. M., \& Nagy, G. (2016). Students' perceptions of Person-Environment fit: Do fit perceptions predict academic success beyond personality traits? Journal of Career Assessment, 24(2), 270-288. doi:10.1177/1069072715580325

Eyel, C. Ş., Kaplan, B., \& Ünkaya, G. (2020). The effect of business administration students' individual values on their entrepreneurial tendency in Istanbul. Economics and Sociology, 13(4), 187-212. doi:10.14254/2071-789X.2020/13$4 / 12$

Franco, M., \& Haase, H. (2020). The role of reputation in the business cooperation process: Multiple case studies in small and medium-sized enterprises. Journal of Strategy and Management, 14(1), 82-95. doi:10.1108/JSMA-012020-0012

Çera, G., Cepel, M., Zakutna, S., \& Rozsa, Z. (2018). Gender differences in perception of the university education quality as applied to entrepreneurial intention. Journal of International Studies, 11(3), 147-160. doi:10.14254/2071$8330.2018 / 11-3 / 13$

Goktan, A. B., \& Gupta, V. K. (2015). Sex, gender, and individual entrepreneurial orientation: Evidence from four countries. International Entrepreneurship and Management Journal, 11(1), 95-112. doi:10.1007/s11365-013-0278-Z

Goraczkowska, J. (2020). Enterprise innovation in technology incubators and university business incubators in the context of polish industry. Oeconomia Copernicana, 11(4), 799-817. doi:10.24136/OC.2020.032

Gruenhagen, J. H. (2020). Returnee entrepreneurship: How home-country institutions, estrangement and support influence entrepreneurial intentions. Journal of Entrepreneurship in Emerging Economies, doi:10.1108/JEEE-052020-0143

Gürol, Y., \& Atsan, N. (2006). Entrepreneurial characteristics amongst university students: Some insights for entrepreneurship education and training in turkey. Education and Training, 48(1), 25-38. doi:10.1108/00400910610645716

Hahn, D., Minola, T., Bosio, G., \& Cassia, L. (2020). The impact of entrepreneurship education on university students' entrepreneurial skills: A family embeddedness perspective. Small Business Economics, 55(1), 257-282. doi:10.1007/s11187-019-00143-y

Hair, J. F. et al. (2010). Multivariate data analysis: A global perspective. 7th Edition. Upper Saddle River, NJ: Pearson Prentice Hall.

Heck, R. K. Z. et al. (2006). The family's dynamic role within family business entrepreneurship. In Handbook of research on family business. Edward Elgar Publishing Ltd. 2006.

Huggins, R., Prokop, D., \& Thompson, P. (2017). Entrepreneurship and the determinants of firm survival within regions: Human capital, growth motivation and locational conditions. Entrepreneurship and Regional Development, 29(3-4), 357-389. doi:10.1080/08985626.2016.1271830

Hussain, T., Mahmood, H., Iqbal, A., Mustafa, G. and Furqan, M. (2021). Fiscal Policy Cyclicality, Governance, and Quality of Institutions Nexus in Ireland. Montenegrin Journal of Economics, 17(3), 111-119. doi: 10.14254/18005845/2021.17-3.9

Chaita, M. V., \& Sibanda, W. (2021). The role of knowledge in enhancing SME innovation: The case of knowsleynorthwest region of england. International Journal of Knowledge Management, 17(1), 93-112. doi:10.4018/IJKM.2021010106

James, A. T. (1964). Distribution of matrix variates and latent roots derived from normal samples. The Annals of Mathematical Statistics, 35(2), 475-501. doi: 10.1214/aoms/11777703550

Jones, J., \& Corral de Zubielqui, G. (2017). Doing well by doing good: A study of university-industry interactions, innovationess and firm performance in sustainability-oriented australian SMEs. Technological Forecasting and Social Change, 123, 262-270. doi:10.1016/j.techfore.2016.07.036 
Jones, P., Miller, C., Jones, A., Packham, G., Pickernell, D., \& Zbierowski, P. (2011). Attitudes and motivations of polish students towards entrepreneurial activity. Education and Training, 53(5), 416-432. doi:10.1108/0040091111114772

Kallas, E., \& Parts, E. (2020). From entrepreneurial intention to enterprise creation: The case of estonia. Journal of Entrepreneurship in Emerging Economies, doi:10.1108/JEEE-07-2020-0235

Khan, K.A., Çera, G., Netek, V. (2019) Perception of the Selected Business Environment Aspects by Service Firms. In Journal of Tourism and Services, 10(19), 111-127. doi: 10.29036/jots.v10i19.115

Klyver, K., Schenkel, M. T., \& Nielsen, M. S. (2020). Can't always get what I want: Cultural expectations of emotional support in entrepreneurship. International Small Business Journal: Researching Entrepreneurship, 38(7), 677-690. doi:10.1177/0266242620915675

Klyver, K., Honig, B., \& Steffens, P. (2018). Social support timing and persistence in nascent entrepreneurship: Exploring when instrumental and emotional support is most effective. Small Business Economics, 51(3), 709-734. doi:10.1007/s11187-017-9964-5

Kuncová, M., \& Mulač, P. (2017). Comparison of the higher education systems in the visegrad group of countries. Turkish Online Journal of Educational Technology, 2017 (October Special Issue INTE), 582-594.

Lancaster, H. O., \& Hamdan, M. A. (1964). Estimation of the correlation coefficient in contingency tables with possibly nonmetrical characters. Psychometrika, 29(4), 383-391. doi:10.1007/BF02289604

Lanero, A., Vázquez, J. -., \& Aza, C. L. (2016). Social cognitive determinants of entrepreneurial career choice in university students. International Small Business Journal: Researching Entrepreneurship, 34(8), 1053-1075. doi: $10.1177 / 0266242615612882$

Lewandowska, A., \& Stopa, M. (2018). SMEs innovativeness and institutional support system: The local experiences in qualitative perspective. polish case study. Oeconomia Copernicana, 9(2), 333-351. doi:10.24136/oc.2018.017

Li, J., \& Valliant, R. (2011). Linear regression influence diagnostics for unclustered survey data. Journal of Official Statistics, 27(1), 99-119.

Luchko, M., Arzamasova, O., \& Vovk, I. (2019). Personnel potential of national economy and gross domestic product: The case of Ukraine. Montenegrin Journal of Economics, 15(2), 59-70. doi:10.14254/1800-5845/2019.15-2.5

Marques, C. S. E., Santos, G., Galvão, A., Mascarenhas, C., \& Justino, E. (2018). Entrepreneurship education, gender and family background as antecedents on the entrepreneurial orientation of university students. International Journal of Innovation Science, 10(1), 58-70. doi:10.1108/IJIS-07-2017-0067

Marikina, M. (2018). The Impact of Ecological Regulations and Management on National Competitiveness in the Balkan States. Journal of Competitiveness, 10(4), 120-135. doi: 10.7441/ joc.2018.04.08

Mishchuk, H., Samoliuk, N., \& Bilan, Y. (2019). Measuring social justice in the light of effectiveness of public distributive policy. Administration \& Public Management Review, (32). 63-76. DOI: 10.24818/amp/2019.32-05

Moon, S., Jalali, N., \& Erevelles, S. (2021). Segmentation of both reviewers and businesses on social media. Journal of Retailing and Consumer Services, 61 doi:10.1016/j.jretconser.2021.102524

Nabi, G., Walmsley, A., Liñán, F., Akhtar, I., \& Neame, C. (2018). Does entrepreneurship education in the first year of higher education develop entrepreneurial intentions? the role of learning and inspiration. Studies in Higher Education, 43(3), 452-467. doi:10.1080/03075079.2016.1177716

Nava, N., Di Matteo, T., \& Aste, T. (2018). Financial time series forecasting using empirical mode decomposition and support vector regression. Risks, 6(1) doi:10.3390/risks6010007

Ojewumi, K.A., \& Fagbenro, D.A. (2019). Entrepreneurial intention among polytechnic students in Nigeria: the role of self- efficacy and social networks. International Journal of Entrepreneurial Knowledge, 7(1), 20-30. doi: $10.37335 /$ ijek.v7i1.85

OECD (2018). Indicators: Education at a Glance. Centre for Educational research and innovation. OECD Publishing, Paris460. doi: 10.1787/eag-2018-en

Partanen, J., \& Goel, S. (2017). Interplay between reputation and growth: The source, role and audience of reputation of rapid growth technology-based SMEs. Entrepreneurship and Regional Development, 29(3-4), 238-270. doi:10.1080/08985626.2016.1262908 
Popescu, C. C., Bostan, I., Robu, I. -., Maxim, A., \& Diaconu (Maxim), L. (2016). An analysis of the determinants of entrepreneurial intentions among students: A romanian case study. Sustainability (Switzerland), 8(8) doi:10.3390/su8080771

Ramos-González, M. M., Rubio-Andrés, M., \& Sastre-Castillo, M. Á. (2021). Effects of socially responsible human resource management (SR-HRM) on innovation and reputation in entrepreneurial SMEs. International Entrepreneurship and Management Journal, doi:10.1007/s11365-020-00720-8

Robertson, M., Line, M., Jones, S., \& Thomas, S. (2000). International students, learning environments and perceptions: A case study using the delphi technique. Higher Education Research and Development, 19(1), 89-102. doi:10.1080/07294360050020499

Rodríguez-Gulías, M. J., Gabriel, V. M. S., \& Rodeiro-Pazos, D. (2020). The effect of good governance on business creation: A multilevel approach. Revista De Economia Mundial, 2020(54), 21-42. doi:10.33776/rem.v0i54.3825

Rogalska, E. (2018). Multiple-criteria analysis of regional entrepreneurship conditions in Poland. Equilibrium. Quarterly Journal of Economics and Economic Policy, 13(4), 707-723. doi: 10.24136/eq.2018.034

Sansone, G., Battaglia, D., Landoni, P., \& Paolucci, E. (2021). Academic spinoffs: The role of entrepreneurship education. International Entrepreneurship and Management Journal, 17(1), 369-399. doi:10.1007/s11365-019-00601-9

Sobekova Majkova, M., \& Kljucnikov, A. (2017). Insolvency risk and problems with receivables payments in the environment of the slovak small and medium-sized enterprises and young entrepreneurs. Journal of Applied Economic Sciences, 12(7), p. 2028-2037.

van Stel, A., Kaciak, E., \& Cieślik, J. (2020). Hiring plans by solo entrepreneurs at the time of start-up: The role of education and the desire for self-expression. Journal of Business Research, 119, 58-66. doi:10.1016/j.jbusres.2020.06.060

Suroso, A., Rafinda, A \& Gal, T. (2020). The evaluation of entrepreneur incubation program at higher education. International Journal of Entrepreneurial Knowledge, 8(2), 14-26. doi: 10.37335/ijek.v8i2.113

Turulja, L., Agic, E., \& Veselinovic, L. (2020). Motivation of the youth of bosnia and herzegovina to start a business: Examining aspects of education and social and political engagement. Economic Research-Ekonomska Istrazivanja, 33(1), 2692-2712. doi:10.1080/1331677X.2019.1706602

Tvaronavičiené, M., Mazur, N., Mishchuk, H., \& Bilan, Y. (2021). Quality of life of the youth: assessment methodology development and empirical study in human capital management. Economic Research-Ekonomska Istraživanja, 1-18. DOI:10.1080/1331677X.2021.1956361

Vašenda, J. (2019). Visegrad group countries compared through world university rankings. International Education Journal, 18(3), 100-115.

Vega-Gómez, F. I., Miranda González, F. J., \& Pérez-Mayo, J. (2020). Analyzing the effects of institutional- and ecosystem-level variables on university spin-off performance. SAGE Open, 10(2) doi: $10.1177 / 2158244020931116$

de Waal, D. J. (1977). Asymptotic distributions for the elementary symmetric functions of two matrices under the assumption of linearity. Journal of Multivariate Analysis, 7(1), 223-228. doi:10.1016/0047-259X(77)90042-2

Zajkowski, R., \& Domańska, A. (2019). Differences in perception of regional pro-entrepreneurial policy: Does obtaining support change a prospect?. Oeconomia Copernicana, 10(2), 359-384. doi:10.24136/oc.2019.018

Zhu, Q., Choi, J., \& Meng, Y. (2021). The impact of no-loan policies on student economic diversity at public colleges and universities. Research in Higher Education, 62(6), 733-764. doi:10.1007/s11162-020-09621-9

Zaring, O., Gifford, E., \& McKelvey, M. (2021). Strategic choices in the design of entrepreneurship education: An explorative study of swedish higher education institutions. Studies in Higher Education, 46(2), 343-358. doi:10.1080/03075079.2019.1637841

Zygmunt, J. (2018). Entrepreneurial activity drivers in the transition economies. Evidence from the Visegrad countries. Equilibrium. Quarterly Journal of Economics and Economic Policy, 13(1), 89-103. doi: 10.24136/eq.2018.005

Yousaf, U., Ali, S. A., Ahmed, M., Usman, B., \& Sameer, I. (2021). From entrepreneurial education to entrepreneurial intention: A sequential mediation of self-efficacy and entrepreneurial attitude. International Journal of Innovation Science, doi:10.1108/IJIS-09-2020-0133 